(C) 2017

Мельничук В. В., кандидат ветеринарних наук

Полтавська державна аграрна академія

\title{
ЕКСПЕРИМЕНТАЛЬНЕ ВИЗНАЧЕННЯ ДЕЗІНВАЗІЙНИХ ВЛАСТИВОСТЕЙ ЗАСОБУ «АНОЛІТ КРИСТАЛ»
}

\section{Рецензент - доктор ветеринарних наук, професор А. А. Замазій}

У роботі наведені результати досліджень дезінвазійної активності дезінфікуючого засобу «Аноліт кристал» стосовно тест-культур яєць Ascaris suum, Trichuris ovis, Trichuris skrjabini ma Trichuris globulosa, за показниками дезінвазійної ефективності (ДЕ). Експериментально встановлено, щзо дезінфікуючий засіб володіє вираженими дезінвазійними властивостями щзодо дослідних тест-культур; A. sиит - у розведенні 1:3, 1:2, 1:1 та без попереднього розведення за всіх експозииій (ДЕ - 90,53100,00\%); T. ovis - y розведенні 1:2 за експозииіі 60 хв., 1:1 та без попереднього розведення за всіх експозииій (ДЕ - 94,85-100,00\%); T. skrjabini - у розведенні 1:3 за експозииії 30 mа 60 хв., 1:2, 1:1 та без попереднього розведення за всіх експозицій (ДЕ 92,31-100,00\%); T. globulosa - у розведенні 1:3; 1:2; 1:1 $і$ без попереднього розведення за всіх експозичій (ДЕ-94,38-100,00\%).

Ключові слова: дезінфікуючі засоби, дезінвазійні властивості, тест-культура, Ascaris suит, Trichuris ovis, Trichuris skrjabini, Trichuris globulosa.

Постановка проблеми. Тваринництво традиційно є однією 3 провідних галузей аграрного виробництва, яка, в свою чергу, визначає продовольчу безпеку держави. На сьогодні погіршення економічного становища в державі неминуче призвело до втрат у сільському господарстві, що відобразилося значним скороченням чисельності поголів'я тварин у господарствах різних форм власності. Однією з причин зменшення поголів'я в країні $є$ енерговитратні засоби утримання та годівлі, що неминуче впливає на собівартість отримуваної від тварин продукції. Тому важливим на сьогодні $є$ пошук нових підходів у господарській діяльності $з$ метою отримання високоякісної тваринницької продукції та шляхів зниження iі собівартості. Саме галузь вівчарства $\epsilon$ перспективною в цьому напрямі $[4,8]$

Адже відомо, що вівці є найменш вибагливими тваринами до кормової бази завдяки особливостям в анатомічній будові травного апарату.

За правильного підходу в літній період вони можуть давати високі прирости навіть на збіднілих і непридатних для інших тварин пасовищах
$[1,5]$. До плюсів також можна віднести велику різноманітність видів отримуваної продукції, що забезпечує високу сумарну ефективність використання поживних речовин корму. Тому виробництво продукції вівчарства належить до економічно вигідних галузей тваринництва [11]. Поряд 3 великою кількістю переваг виробництво продукції вівчарства також має певні ризики внаслідок постійно зростаючої кількості різноманітних хвороб заразної етіології, серед яких вагоме місце належить захворюванням, збудниками яких $є$ різні види нематод. Останні завдають галузі значних економічних збитків, що виражаються у відставанні в рості та розвитку тварин, зниженні їх продуктивності (удій молока, настриг вовни, приріст живої ваги, вихід приплоду), а в окремих випадках навіть призводити до загибелі [9].

Аналіз основних досліджень і публікацій, у яких започатковано розв'язання проблеми. Як відомо, одним із факторів передачі інвазійних захворювань є об'єкти зовнішнього середовища (приміщення для утримання тварин, підстилка, підлога, годівниці, інвентар) контаміновані яйцями і личинками збудників ендопаразитарних захворювань [2]. Загальновідомо, що найбільша інтенсивність забруднення характерна для грунту - місця тимчасового зберігання інвазійних елементів, їх природного резервуару $[6,7]$. Тому дезінвазія цих місць вважається одним з вирішальних заходів у боротьбі з паразитами, оскільки знищення у зовнішньому середовищі інвазійного начала призводить до розриву ланки в епізоотичному ланцюгу паразитарних захворювань. Незважаючи на необхідність проведення зазначеного заходу, найчастіше ним нехтують. В значній мірі це обумовлено відсутністю, нестачею у виборі дезінвазійних засобів або їх високою вартістю на ринку ветеринарних препаратів [3, 10]. Тому вивчення дезінвазійних властивостей нових та перспективних дезінфікуючих засобів $€$ актуальним питанням.

Мета досліджень полягала у встановленні дезінвазійних властивостей дезінфікуючого засобу «Аноліт кристал». 


\section{ВЕТЕРИНАРНА МЕДИЦИНА}

Завданням досліджень було визначити дезінвазійну ефективність засобу щодо тест-культур інвазійних яєць аскарисів та трихурисів у лабораторних умовах.

Матеріали і методи досліджень. Роботу виконували на базі наукової лабораторії паразитології кафедри паразитології та ветеринарносанітарної експертизи Полтавської державної аграрної академії впродовж 2017 року.

В якості тест-культур для дослідження дезінвазійних властивостей засобу «Аноліт кристал» (ПП «Персонал Люкс», Україна) використано інвазійні яйця Ascaris suum - еталон стійкості, Trichuris ovis, Trichuris skrjabini та Trichuris globulosa, збудників нематодозів тварин. Для дослідження було підготовлено одну контрольну та 96 дослідних чашок Петрі з різним розведенням засобу $(1: 7 ; 1: 6 ; 1: 5 ; 1: 4 ; 1: 3 ; 1: 2 ; 1: 1 ;$ у концентрованому вигляді - без попереднього розведення) та 3 різною експозицією $(10,30,60$ хв.). До попередньо підготовленої суміші яєць тесткультур додавали аналогічний об'єм розчину препарату певної концентрації. Після відповідної експозиції суміш яєць чотириразово відмивали в дистильованій воді. Чашки Петрі із сумішшю яєць гельмінтів поміщали в термостат за температури $27^{\circ} \mathrm{C}$, і упродовж 15 діб вели спостереження. Через кожні три доби культури розглядали під мікроскопом (Ч100, Ч400). Відзначали загальний вигляд яєць гельмінтів, враховуючи зміни оболонки, деформацію зародків та стан розвитку зародків або їх пошкодження.

Дезінвазійну ефективність (ДЕ) визначали згідно 3 загальноприйнятою формулою. Оцінку дезінвазійної ефективності проводили за показ- никами: високий рівень ефективності - від 90 до $100 \%$, задовільний - від 60 до $90 \%$, незадовільний - до $60 \%$.

Результати дослідження. Під час проведення дослідження дезінвазійної ефективності засобу «Аноліт кристал» на дослідних тест-культурах інвазійних яєць встановлено, що найвищі показники $(100 \%)$ дезінвазійної ефективності (ДЕ) щодо тест-культури яєць: Ascaris suum, засіб показав у розведеннях 1:2 - за експозицій 30 та 60 хв., а також 1:1 та без попереднього розведення за всіх експозицій; Trichuris ovis - у розведенні 1:1 та без попереднього розведення за всіх експозицій; Trichuris skrjabini - в розведенні 1:2 за експозиції 30 й 60 хвилин, та у розведенні $1: 1$ i без попереднього розведення за всіх експозицій; Trichuris globulosa у розведенні 1:2 та 1:1 і без попереднього розведення за всіх експозицій (див. табл.).

Під час вивчення дезінвазійної ефективності препарату на інвазійних яйцях Ascaris suum зареєстровано, що препарат у розведенні 1:7 та 1:6 за всіх запропонованих експозицій $(10,30,60$ хв.) володіє незадовільним рівнем ефективності, показник дезінвазійної ефективності (ДЕ) за вищевказаних розведень знаходиться в межах 13,68-51,58 \%. Збільшення концентрації препарату призводило до підвищення його дезінвазійної ефективності. Так, задовільний рівень ефективності зареєстрований за розведення препарату 1:5 та 1:4 за всіх експозицій (ДЕ - 65,26$88,42 \%)$. Високим рівнем ефективності препарат «Аноліт кристал» володів у розведеннях 1:3, 1:2, $1: 1$ та без попереднього розведення у вигляді (ДЕ - 90,53-100,00\%).

Дезінвазійна ефективність засобу щодо тест-культур інвазійних ясць нематод (n=100), \%

\begin{tabular}{|c|c|c|c|c|c|c|c|c|c|}
\hline \multirow{2}{*}{ Експозиція, хв. } & \multirow{2}{*}{ Тест-культура } & \multicolumn{7}{|c|}{ Розведення препарату } & \multirow{2}{*}{ Без розведення } \\
\cline { 3 - 10 } & $1: 7$ & $1: 6$ & $1: 5$ & $1: 4$ & $1: 3$ & $1: 2$ & $1: 1$ & \\
\hline \multirow{5}{*}{10} & A. suum & 13,68 & 35,79 & 65,26 & 81,05 & 90,53 & 97,89 & 100,00 & 100,00 \\
\cline { 2 - 10 } & T. ovis & 5,15 & 31,96 & 49,48 & 68,04 & 84,54 & 94,85 & 100,00 & 100,00 \\
\cline { 2 - 10 } & T. skrjabini & 8,79 & 38,46 & 59,34 & 76,92 & 87,91 & 98,90 & 100,00 & 100,00 \\
\cline { 2 - 10 } & T. globulosa & 11,24 & 40,45 & 61,80 & 78,65 & 94,38 & 100,00 & 100,00 & 100,00 \\
\hline \multirow{5}{*}{30} & A. suum & 18,95 & 46,32 & 69,47 & 84,21 & 92,63 & 100,00 & 100,00 & 100,00 \\
\cline { 2 - 9 } & T. ovis & 15,46 & 40,21 & 56,70 & 73,20 & 87,63 & 96,91 & 100,00 & 100,00 \\
\cline { 2 - 9 } & T. skrjabini & 12,09 & 48,35 & 67,03 & 81,32 & 92,31 & 100,00 & 100,00 & 100,00 \\
\cline { 2 - 9 } & T. globulosa & 14,61 & 49,44 & 68,54 & 83,15 & 96,63 & 100,00 & 100,00 & 100,00 \\
\hline \multirow{3}{*}{60} & A. suum & 27,37 & 51,58 & 74,74 & 88,42 & 96,84 & 100,00 & 100,00 & 100,00 \\
\cline { 2 - 9 } & T. ovis & 22,68 & 44,33 & 62,89 & 79,38 & 91,75 & 98,97 & 100,00 & 100,00 \\
\cline { 2 - 8 } & T. skrjabini & 24,18 & 54,95 & 69,23 & 85,71 & 96,70 & 100,00 & 100,00 & 100,00 \\
\cline { 2 - 8 } & T. globulosa & 25,84 & 57,30 & 70,79 & 89,89 & 98,88 & 100,00 & 100,00 & 100,00 \\
\hline
\end{tabular}




\section{ВЕТЕРИНАРНА МЕДИЦИНА}

Під час вивчення дезінвазійної ефективності препарату на інвазійних яйцях Trichuris ovis встановлено, що розведення препарату 1:7; 1:6 за експозицій 10, 30 та 60 хв., а також розведення засобу 1:5 за експозицій 10 та 30 хв. призводить до незадовільної ефективності досліджуваного препарату (ДЕ - 5,15-56,70 \%). Слід відмітити, що зі збільшенням експозиції до 60 хв. розведення засобу «Аноліт кристал» 1:5 має задовільний рівень ефективності (ДЕ - 62,89\%). Також задовільний рівень щодо інвазійних яєць T. ovis зареєстровано за розведення засобу 1:4 за всіх експозицій (ДЕ - 68,04-79,38 \%) та у розведенні $1: 3$ за експозицій 10 та 30 хв. - ДЕ - 84,54 та $87,63 \%$ відповідно. Високий рівень дезінвазійної ефективності препарат «Аноліт кристал» має за розведення 1:2 та експозиції 60 хв. - ДЕ $91,75 \%$, а також у розведенні $1: 1$ та без попереднього розведення за всіх експозицій (ДЕ94,85-100,00\%).

Під час вивчення дезінвазійної ефективності препарату на інвазійних яйцях Trichuris skrjabini зареєстровано, що розведення препарату 1:7; 1:6 за всіх експозицій, та розведення засобу 1:5 за експозиції 10 хв. призводить до незадовільного рівня ефективності (ДЕ - 8,79-54,95\% та 59,34 \% відповідно). Використання засобу «Аноліт кристал» за розведення 1:5 з експозицією 30 та 60 хв.; розведення 1:4 за всіх експозицій (10, 30, 60 хв.); розведення 1:3 за експозиції 10 хв. показали задовільний рівень ефективності щодо інвазійної культури яєць T. skrjabini (ДЕ - 67,03$69,23 \%$; 76,92-85,71\%; 87,91\%). Високий рівень дезінвазійної ефективності зареєстровано в разі використання засобу в розведенні 1:3 за експозиції 30 та 60 хв., а також 1:2, 1:1 та без попереднього розведення за всіх запропонованих експозицій (ДЕ - 92,31-100,00 \%).

Дослідженнями встановлено, що використан-

\section{БІБЛІОГРАФІЯ}

1. Бова В. М. Багаторічні кормові культури у виробництві зелених кормів для овець на півдні України / В. М. Бова // Міжвід. темат. наук. зб. «Вівчарство». - Вип. 27. - К. : Урожай, 1990. C. 62-64.

2. Буров В. В. О загрязнённости обьектов окружающей среды инвазионными элементами кишечных нематод свиней / В. В. Буров, С. Н. Белозёров // Тез. 1-й городской научн. конф. аспирантов и соискателей. - Киров, 2000. - C. 39-40.

3. Васильев В. А. Эффективность средств дезинвазии объектов внешней среды / В. А. Васильев // Дезинфекционное дело. - 2004. - №6. - ня засобу «Аноліт кристал» щодо інвазійної культури яєць $T$. globulosa у розведенні 1:7 та 1:6 за всіх запропонованих експозицій призводить до незадовільного рівня ефективності (ДЕ 11,24-57,30\%). Застосування засобу в разі зменшення розведення до 1:5 й 1:4 за всіх експозицій призводило до задовільного рівня його ефективності (ДЕ - 61,80-89,89\%). Засіб за розведення $1: 3 ; 1: 2 ; 1: 1$ та без попереднього розведення за всіх експозицій володів високим рівнем ефективності (ДЕ - 94,38-100,00 \%).

Отже, під час проведення експериментальних досліджень препарату «Аноліт кристал» у лабораторних умовах встановлено виражені дезінвазійні властивості засобу щодо тест-культур інвазійних яєць Ascaris suum, Trichuris ovis, Trichuris skrjabini та Trichuris globulosa.

\section{Висновки:}

1. Експериментальними дослідженнями встановлено, що засіб «Аноліт кристал» володіє дезінвазійними властивостями щодо інвазійних яєць Ascaris suum, Trichuris spp.

2. Високий рівень дезінвазійної ефективності забезпечує використання препарату «Аноліт кристал» щодо культур яєць: Ascaris suum - у розведенні 1:3, 1:2, 1:1 та в концентрованому вигляді за всіх експозицій; Trichuris ovis - у розведенні: 1:2 за експозиції 60 хв., 1:1 та без попереднього розведення за всіх експозицій; Trichuris skrjabini - у розведенні: 1:3 за експозиції 30 та 60 хв., 1:2, 1:1 та без попереднього розведення за всіх експозицій; Trichuris globulosa - у розведенні $1: 3 ; 1: 2 ; 1: 1$ та без попереднього розведення за всіх концентрацій.

Перспективи подальших розвідок у даному напрямі. В подальшому планується проведення вивчення дезінвазійної ефективності засобу «Аноліт кристал» в умовах виробництва.

C. 28-31.

4. Вдовиченко Ю. В. Стан та перспективи розвитку галузі вівчарства України / Ю. В. Вдовиченко, П. Г. Жарук // Вісник Дніпропетровського державного аграрного університету. - 2013. - №1. - С. 136-138. - Режим доступу : http://nbuv.gov.ua/UJRN/vddau 2013136.

5. Головач М. Й. Біологічні особливості та господарські показники помісних овець прекос Ч латвійська темноголова і прекос Ч ромні-марш в умовах Прикарпаття : автореф. дис. на здобуття наук. ступеня к. с.-г. н. / М. Й. Головач. - Львів, 1996. -23 c. 


\section{ВЕТЕРИНАРНА МЕДИЦИНА}

6. Дахно I. C. Екологічна гельмінтологія / I. С. Дахно, Ю. І. Дахно. - Суми : Козацький вал, 2010. $-220 \mathrm{c}$.

7. Луценко Л. И. Внешняя среда - фактор передачи гельмитоантро-позоонозов / Л.И.Луценко // Проблемы и перспективы паразитоценологии / V междунар. конф. паразитоценологов Украины, 1997 г. : тезисы докл. - ХарьковЛуганск, 1997. - С. 102-103.

8. Офіційний сайт Державної служби статистики [Електронний ресурс]: Статистична інформація по тваринництву України - Режим доступу: http://www.ukrstat.gov.ua/operativ/operativ 2005/sg/ph/ph_u/arh_ph 2005.html.

9. Сафиуллин Р. T. Распостранение и экономический ущерб от основных гельминтозов жвачных животных / Р. Т. Сафиуллин // Ветеринария. - 1997. - №6. - C. 32.

10. Черепанов A. A. Концепция противопаразитарных мероприятий для решения научных и практических задач / А. А. Черепанов // Тр. ВИГИСа. - 1999. - Т. 35. - С. 159-161.

11. Шелест Л. С. Оцінка стратегічного потенціалу вівчарства степової зони України : моногр. / Л. С. Шелест. - Асканія-Нова, 2009. - 164 с. 